\title{
ANALISIS FAKTOR-FAKTOR YANG MEMPENGARUHI MINAT BERWIRAUSAHA MAHASISWA PROGRAM STUDI MANAJEMEN UNIVERSITAS MUHAMMADIYAH GRESIK
}

\section{Ragil Dian Asmoro}

Program Studi Manajemen-Fakultas Ekonomi dan Bisnis

Universitas Muhammadiyah Gresik

\begin{abstract}
This research purposed to achieve empirical evidence about factors affecting the interest in entrepreneurship. All predictor variable are entrepreneurship education, skills, and environtment. This research placed in University of Muhammadiyah Gresik. The number of respondend stated 31 colloge students from magement departmentfocused in entrepreneurship concern. Multiple regression used to test the hipothesys. The result find the empirical evidence that skills and environtment affecting the interest in entrepreneurship. Meanwhile, entrepreneurship education doesn't influence the interest in entrepreneurship significantly.
\end{abstract}

Keywords : Interest in entrepreneurship, Education, Skills, environtment.

\section{PENDAHULUAN}

Indonesia merupakan salah satu negara yang sedang berkembang. Perkembangan Indonesia utamanya terlihat pada aspek ekonomi. Luasnya negara Indonesia memaksa pemerataan kesejahteraan dan pertumbuhan ekonomi di setiap daerah sulit dicapai. Akibat dari hal tersebut adalah kesenjangan ekonomi yang cukup signifikan. Masih banyak masyarakat yang hidup di bawah garis kemiskinan. Banyaknya masyarakat yang berpendapatan rendah, tidak memiliki pekerjaan (pengangguran), sehingga tidak dapat memenuhi berbagai kebutuhan hidupnya.

Selama beberapa tahun terakhir, isu yang berkembang adalah mengenai persaingan global. Persaingan global memaksa setiap negara untuk meningkatkan kompetensi sumber daya manusianya. Implikasi dari hal tersebut adalah entitas atau perusahaan menetapkan standar kompetensi yang tinggi untuk rekrutmen karyawan. Angkatan kerja di Indonesia masih belum siap dengan standar kompetensi yang tinggi tersebut. Karena banyak angkatan kerja yang tidak dapat memenuhi standar yang ditetapkan perusahaan, memaksa angkatan kerja menjadi pengangguran. Badan Pusat Statistik (BPS) dan Ketenagakerjaan Indonesia mencatat pengangguran di Indonesia mencapai angka 7,03 juta orang per Agustus 2016 (Fauzi, 2016). Ironisnya, sebagian dari pengangguran tersebut adalah lulusan sarjana. Tercatat sejumlah 495.143 orang pengangguran merupakan orang yang terdidik dan merupakan kalangan intelektual (Pratiwi dan Wardana, 2016).

Dewasa ini, fenomena yang terjadi adalah sulitnya mencari pekerjaan. Bahkan lulusan sarjana pun kesulitan untuk masuk ke bursa kerja yang tersedia karena kompetensi yang tidak memenuhi standar. Padahal, lulusan sarjana telah dipersiapkan dengan baik oleh universitas untuk memenuhi permintaan pasar kerja oleh korporasi. Kurikulum pendidikan untuk tingkat sarjana telah didesain sedemikian rupa agar dapat menciptakan lulusan yang siap kerja. Namun, kenyataan yang terjadi, berbanding terbalik dengan tujuan dari desain kurikulum pendidikan tersebut. Faktanya, masih banyak lulusan sarjana yang menganggur karena tersisih dari bursa kerja.

Pengangguran merupakan masalah yang meresahkan bagi banyak pihak. Apalagi dengan perguruan tinggi yang terus menelurkan lulusan-lulusan baru setiap tahunnya. Ketika lulusan perguruan tinggi tersebut tidak mampu memenuhi kompetensi, maka semakin banyak jumlah pengangguran di Indonesia, dan kaum intelektual juga tutut hadir dalam klasifikasi ini. 
Sering kali, apa yang menjadi tujuan universitas yang dinyatakan secara eksplisit dalam visi misinya tidak sejalan dengan Mindset para mahasiswanya. Orientasi mahasiswa seperti sudah terdikotomi pada premis "kuliah adalah jembatan untuk mencari kerja". Oktarilis (2012) menyebutkan bahwa minat mahasiswa untuk mencari kerja lebih dominan daripada menciptakan lapangan kerja sendiri dengan berwirausaha. Bekerja pada suatu perusahaan dinilai lebih prestisius oleh mahasiswa dari segi gaji, status sosial, dan lain sebagainya (Oktarilis, 2012). Desain kurikulum pendidikan seyogyanya tidak hanya menitikberatkan pada orientasi membentuk mahasiswa menjadi lulusan sarjana yang berkompetensi sesuai permintaan pasar kerja. Lebih dari itu, kurikulum pendidikan akan lebih bijak ketika mampu menciptakan lulusan yang mampu berinovasi dan berkreatifitas. Implikasinya adalah membangun Mindset mahasiswa agar mampu menjadi pencipta lapangan kerja. Menurut Turker dan Selcuk dalam Pratiwi dan Wardana (2016) mengemukakan bahwa pendidikan yang ditawarkan universitas mampu mempengaruhi pemilihan karir mahasiswa sebagai wirausaha.

Peran Perguruan Tinggi (PT) tidak hanya berfokus pada pembekalan hard competence untuk mahasiswa, akan tetapi PT juga berperan dalam membuka cakrawala ilmu yang lebih luas. Pendidik, dalam hal ini dosen berperan dalam memberikan berbagai wawasan kepada mahasiswa. Agar mahasiswa tidak hanya berorientasi menjadi pencari kerja setelah lulus, perlu diberikan pendidikan kewirausahaan.

Penting bagi universitas untuk menumbuhkan jiwa entrepreneur kepada mahasiswa. Hal ini ditujukan agar mahasiswa tidak termakan doktrin kuliah hanya untuk mencari kerja. Minat mahasiswa untuk berwirausaha perlu dibangun sejak pertama kali duduk di bangku kuliah.

Sama halnya dengan universitas yang lain, Universitas Muhammadiyah Gresik (UMG) juga bertujuan untuk menciptakan lulusan yang siap kerja, memiliki kompetensi seperti yang diminta oleh pasar kerja, serta mempunyai jiwa wirausaha (entrepreneurship). Tujuan tersebut diekstensikan secara umum melalui motto UMG, yaitu The Power of Islamic Entrepreneurship. Motto UMG tersebut secara sederhana dijadikan dasar untuk menciptakan lulusan yang memiliki jiwa wirausaha berlandaskan nilai-nilai islam. Satuan unit yang secara esensi memiliki otoritas untuk pengembangan entrepreneurship adalah program studi, lebih spesifik program studi manajemen. Paparan visi program studi manajemen UMG yakni menghasilkan sarjana ekonomi di bidang manajemen dan wirausaha berdasar pada prinsip-prinsip islam tahun 2002. Sedangkan misi prodi manajemen UMG adalah menyelanggarakan pendidikan manajemen dan wirausaha yang berkualitas kepada mahasiswa, dengan menekankan pada kompetensi, profesionalitas, dan moralitas; mengembangkan penelitian di bidang manajemen dan wirausaha yang berlandaskan kompetensi, kewirausahaan, etika, dan tanggung jawab sosial; mengembangkan kemitraan bersama dengan pelaku bisnis beserta masyarakat dalam mengimplementasikan ilmu pengetahuan manajemen dan wirausaha sebagai wujud pengabdian kepada masyarakat. Lulusan prodi manajemen diharapkan berkompetensi untuk menjadi pengusaha, manajer, dan konsultan.

Peminat program studi manajemen terbilang cukup banyak. Tercatat sejumlah 813 mahasiswa prodi manajemen dari empat angkatan terakhir yakni 2013-2016. Secara rinci, distribusi data jumlah mahasiswa prodi manajemen UMG adalah sebagai berikut :

Tabel 1 
Data Mahasiswa Prodi Manajemen UMG

\begin{tabular}{|l|c|c|c|c|c|c|c|c|}
\hline Angkatan & \multicolumn{2}{|c|}{2013} & \multicolumn{2}{c|}{2014} & \multicolumn{2}{c|}{2015} & \multicolumn{2}{c|}{2016} \\
\hline Kelas & Pagi & Sore & Pagi & Sore & Pagi & Sore & Pagi & Sore \\
\hline $\begin{array}{l}\text { Jumlah } \\
\text { Mahasiswa }\end{array}$ & 66 & 98 & 98 & 132 & 89 & 89 & 142 & 99 \\
\hline $\begin{array}{l}\text { Konsentrasi } \\
\text { KWU }\end{array}$ & \multicolumn{2}{|c|}{20} & \multicolumn{2}{|c|}{16} & \multicolumn{2}{|c|}{$\begin{array}{c}\text { Belum } \\
\text { Menempuh }\end{array}$} & $\begin{array}{c}\text { Belum } \\
\text { Menempuh }\end{array}$ \\
\hline
\end{tabular}

Sumber :Badan Administrasi Akademik Universitas Muhammadiyah Gresik

Mengingat banyaknya jumlah mahasiswa pada program studi ini, merupakan suatu tantangan bagi UMG untuk mencetak lulusan yang bukan hanya menjadi pekerja, tetapi mampu untuk menciptakan lapangan kerja. Komitmen program studi manajemen UMG untuk mencetak lulusan yang berkompetensi menjadi seorang entrepreneur dibuktikan dengan beberapa langkah kongkret seperti dibukanya konsentrasi kewirausahaan dan program studi baru yakni program studi kewirausahaan. Konsentrasi kewirausahaan ditujukan untuk memberikan bekal pendidikan kewirausahaan bagi mahasiswa. Hal yang menarik adalah ketika observasi awal, mahasiswa manajemen yang mengambil konsentrasi kewirausahaan tertarik untuk mengambil konsentrasi tersebut karena ingin mengatahui ilmu-ilmu untuk menjadi pengusaha. Bahkan sebagian kecil dari mereka sudah mulai berbisnis secara online. Selain itu mereka juga mengungkapkan rasa ragunya untuk bekerja di perusahaan setelah lulus. Namun, jika merujuk pada data di atas, jumlah mahasiswa yang mengambil konsentrasi kewirausahaan menurun dari tahun 2013 ketahun 2014. Padahal jumlah mahasiswa manajemen angkatan 2014 secara keseluruhan lebih banyak disbanding tahun 2013. Penurunan ini ditengarai karena beberapa informan mengatakan bahwa sebagian mahasiswa manajemen saat memilih konsentrasi mempertimbangkan keminatannya untuk orientasi pekerjaan. Hal ini yang diduga menjadi penyebab turunnya peminat konsentrasi kewirausahaan.

Rochayani (2013) minat adalah ketertarikan atau dorongan yang tinggi dari seseorang untuk melakukan sesuatu guna mewujudkan pencapaian tujuan dan cita-cita yang menjadi keinginannya yang dilakukan dengan penuh kesadaran dan mendatangkan perasaan senang, suka dan gembira.

Untuk dapat membentuk mahasiswa menjadi seorang entrepreneur, perlu diperhatikan faktor-faktor apa saja yang dapat mempengaruhi minat mahasiswa untuk berwirausaha. Dengan memperhatikan faktor-faktor yang mempengaruhi minat mahasiswa untuk berwirausaha, maka dapat dilakukan upaya-upaya untuk menumbuhkan minat berwirausaha pada mahasiswa. Pada akhirnya, tujuan Perguruan Tinggi untuk mencetak lulusan yang mampu menjadi seorang entrepreneur dapat dicapai.

$$
\text { Menurut Sarwoko }
$$

pendidikan kewirausahaan perlu diberikan untuk menanamkan nilai inovatif dan kreatif dalam menanggapi peluang, menciptakan peluang serta keterampilan dan pengetahuan berwirausaha, karena minat berwirausaha merupakan titikawal bagaimana usaha tersebut dijalankan dan bagaimana cara mengelola risiko.

Pendidikan kewirausahaan merupakan salah satu upaya untuk menumbuhkan minat mahasiswa untuk berwirausaha. Melalui konsentrasi atau mata kuliah kewirausahaan, PT dapat memberikan wawasan serta melatih mahasiswa untuk menjadi seorang wirausahawan. Studi tentang pendidikan kewirausahaan sebagai salah satu faktor yang mampu memprediksi minat mahasiswa untuk berwirausaha telah banyak dilakukan. Ardiyani dan Kusuma (2016) menemukan bahwa pendidikan berpengaruh positif terhadap minat berwirausaha. Artinya, ketika mahasiswa memiliki pengetahuan dan wawasan mengenai manfaat berwirausaha, maka minat mereka untuk berwirausaha akan semakin tinggi.

Untuk dapat menciptakan lapangan kerja dengan berbagai kreasi dan inovasi baru, mahasiswa harus terampil. 
Keterampilan merupakan salah satu bekal dalam berwirausaha. Gibb sebagaimana dikutip Irawan (2016) menyatakan bahwa proses kewirausahaan meliputi perilaku, keterampilan dan atribut yang dimiliki seseorang dalam pendidikan kewirausahaan. Chang dan Rieple dalam Irawan dan Mulyadi (2016) mengungkapkan dimensi keterampilan yang harus dimiliki seorang wirausahawan adalah technical skills, management skills, entrepreneurship skills, dan personal maturity skills. Seseorang yang memiliki keterampilan cenderung lebih kreatif dan inovatif dibandingkan yang kurang terampil. Orang yang terampil berarti pandai untuk mengerjakan suatu hal. Dengan berbekal keterampilan, ditengarai akan lebih menumbuhkan minat mahasiswa untuk berwirausaha.

Selain pendidikan dan keterampilan, faktor lingkungan diduga juga mampu mempengaruhi minat mahasiswa untuk berwirausaha. Menurut Alma (2010:7) dorongan membentuk wirausaha juga datang dari lingkungan seperti teman sepergaulan, lingkungan keluarga, sahabat dimana mereka dapat berdiskusi tentang ide wirausaha, masalah yang dihadapi dan cara mengatasi. Menurut Chaplin dalam Amalia

\section{METODELOGI PENELITIAN}

Penelitian ini menggunakan pendekatan kuantitatif. Penelitian kuantitatif merupakan penelitian yang bertujuan untuk mengamati fenomena dengan berdasarkan pada teori untuk diuji dengan menggunakan variabelvariabel dengan proses analisis data menggunakan sejumlah prosedur statistik. Lokasi penelitian ini adalah kampus Universitas Muhammadiyah Gresik. Populasi dalam penelitian ini adalah mahasiswa program studi Manajemen Universitas Muhammadiyah Gresik. Sedangkan sampel penelitiannya adalah mahasiswa program studi Manajemen yang memilih konsentrasi kewirausahaan. Tercatat jumlah sampel penelitian sebanyak 31 orang mahasiswa, dari beberapa

\section{ANALISIS DATA}

\section{Validitas Instrumen}

Berdasarkan hasil uji terhadap item pernyataan yang diajukan kepada responden,
(2015) lingkungan merupakan keseluruhan aspek atau fenomena fisik dan sosial yang mempengaruhi atau dipengaruhi perkembangan individu. Lingkungan berperan sebagai pembentuk model atau pola individu dalam berperilaku. Individu melihat, mempelajari, dan melakukan hal yang diajarkan oleh lingkungan sekitarnya. Lingkungan sekitar yang dimaksud dapat berupa lingkungan keluarga, sekolah, dan masyarakat. Ketika individu berada pada lingkungan yang didominasi para pengusaha, maka individu akan memiliki kecenderungan untuk berwirausaha. Perilaku individu untuk berwirausaha, dibentuk melalui persepsi orang-orang disekitarnya tentang wirausaha. Dorongan lingkungan sekitar kepada individu untuk berwirausaha dapat memicu minat individu untuk berwirausaha. Penelitian Amalia (2015) menemukan bahwa variabel lingkungan berpengaruh terhadap minat untuk berwirausaha.

Berdasarkan penjelasan tersebut, peneliti tertarik untuk meneliti tentang "Analisis Faktor-Faktor Yang Mempengaruhi Minat Berwirausaha Mahasiswa Program Studi Manajemen Universitas Muhammadiyah Gresik".

angkatan. Teknik pengumpulan sampel yang digunakan adalah purposive sampling. Analisis data penelitian dilakukan dengan menggunakan analisis regresi linier berganda. Model yang digunakan dalam penelitian ini dapat dinyatakan dalam rumus berikut :

$$
\begin{array}{ll}
\mathbf{Y} & =\boldsymbol{\alpha}+\boldsymbol{\beta}_{\mathbf{1}} \mathbf{X}_{\mathbf{1}}+\boldsymbol{\beta}_{\mathbf{2}} \mathbf{X}_{\mathbf{2}}+\boldsymbol{\beta}_{\mathbf{3}} \mathbf{X}_{\mathbf{3}}+\boldsymbol{\varepsilon} \\
\text { Dimana } & \\
\mathrm{Y} & =\text { Minat Berwirausaha } \\
\alpha & =\text { Alpha } \\
\beta_{1}-\beta_{3} & =\text { Koefisien Regresi } \\
\mathrm{X}_{1} & =\text { Pendidikan Kewirausahaan } \\
\mathrm{X}_{2} & =\text { Keterampilan } \\
\mathrm{X}_{3} & =\text { Lingkungan } \\
\boldsymbol{\varepsilon} & =\text { Eror }
\end{array}
$$

diperoleh nilai $r$ hitung seluruh item pernyataan untuk seluruh variabel menunjukkan angka yang lebih tinggi dari $r$ tabel. Dengan demikian dapat disimpulkan 
bahwa seluruh item pernyataan yang digunakan valid untuk mengukur variabel

\section{Reliabilitas Jawaban}

Reliabilitas adalah sesuatu instrumen yang bila digunakan beberapa kali untuk mengukur obyek yang sama, akan menghasilkan data yang sama. cukup dapat dipercaya untuk digunakan sebagai alat

Tabel 2 Hasil Uji Reliabilitas

\begin{tabular}{|l|c|c|c|}
\hline \multicolumn{1}{|c|}{ Item } & $\begin{array}{c}\text { Cronbach's } \\
\text { Alpha }\end{array}$ & Reliabilitas & Keterangan \\
\hline Pendidikan Kewirausahaan (X1) & 0,957 & 0,60 & Reliabel \\
\hline Keterampilan (X2) & 0,965 & 0,60 & Reliabel \\
\hline Lingkungan (X3) & 0,949 & 0,60 & Reliabel \\
\hline Minat Berwirausaha (Y) & 0,971 & 0,60 & Reliabel \\
\hline
\end{tabular}

Sumber : Data output SPSS diolah

Berdasarkan di atas nilai

Cronbach's Alphalebih besar dari 0,60.

Dengan demikian dapat disimpulkan bahwa

Asumsi Klasik

Normalitas Data

Tabel 3 Hasil Uji Normalitas - Kolmogorov Smirnof

One-Sample Kolmogorov-Smirnov Test

\begin{tabular}{|ll|r|}
\hline & & $\begin{array}{r}\text { Unstandardiz } \\
\text { ed Residual }\end{array}$ \\
\hline $\mathrm{N}$ & 31 \\
Normal Parameters & a,b & Mean \\
Most Extreme & Std. Dev iation &, 25522979 \\
Diff erences & Absolute &, 113 \\
& Positive &, 062 \\
Kolmogorov-Smirnov Z & Negativ e &,- 113 \\
Asy mp. Sig. (2-tailed) & &, 627 \\
\hline
\end{tabular}

a. Test distribution is Normal.

b. Calculated from data.

Berdasarkan hasil pengujian normalitas tabel 4.13 di atas,maka dapat diketahui bahwa titik-titik (plots), kemudian nilai AssympSig (2-tailed) > 0,05 sehingga pengumpul data karena instrumen tersebut sudah baik. Berdasarkan kriteria Ghozali (2013; 57) syarat untuk dinyatakan memenuhi uji reliabilitas adalah nilai cronbach alpha > 0,6. Dan hasil SPSS untuk uji reliabilitas sebagai berikut : berdasarkan kriteria Ghozali (2013:67). 0,05 dapat disimpulkan bahwa uji normalitas terpenuhi. Diperoleh nilai signifikansi sebesar 0,826>

Multikolinearitas

Tabel 4 Koefisien Tolerance Value Dan VIF Masing-Masing Variabel

\begin{tabular}{|l|c|c|c|}
\hline \multicolumn{1}{|c|}{ Item } & Tolerance & VIF & Keterangan \\
\hline Pendidikan Kewirausahaan (X1) & 0,257 & 3,898 & Nonmultikolinearitas \\
\hline Keterampilan (X2) & 0,105 & 9,568 & Nonmultikolinearitas \\
\hline Lingkungan (X3) & 0,219 & 4,560 & Nonmultikolinearitas \\
\hline
\end{tabular}

Sumber : Data output SPSS diolah 
Berdasarkan tabelhasil uji multikolinearitas di atas, dapat diketahui bahwa nilai Tolerance Value dan VIF dari variabel bebas adalah lebih besar 0,10 dan lebih kecil dari 10 dan dinyatakan tidak

\section{Autokorelasi}

\section{Tabel 5 Nilai Durbin Watson}

\begin{tabular}{|c|c|c|}
\hline & Nilai & Keterangan \\
\hline Durbin Watson & 1,764 & Tidak ada autokorelasi \\
\hline
\end{tabular}

Sumber : Data output SPSS diolah

Berdasarkan tabel 4.15diatas menunjukkan bahwa nilai Durbin Watson 1,764 terletak antara batasatas dU $(1,620)$ dan 4-dU (4 1,620). Berdasarkan kriteria $\mathrm{dU} \leq \mathrm{dw} \leq 4-$ terjadi gejala multikolinearitas dalam perasamaan regresi, sehingga dapat disimpulkan bahwa uji multikolinearitas terpenuhi.

\section{Heteroskedastisitas}

Tabel 6 Heteroskedastisitas

\begin{tabular}{|l|c|c|c|}
\hline \multicolumn{1}{|c|}{ Variabel } & Signifikansi & Alpha & Kesimpulan \\
\hline Pendidikan Kewirausahaan & 0,257 & 0,05 & Homoskedastisitas \\
\hline Keterampilan & 0,248 & 0,05 & Homoskedastisitas \\
\hline Lingkungan & 0,912 & 0,05 & Homoskedastisitas \\
\hline
\end{tabular}

\section{Sumber : Data output SPSS diolah}

Dari tabel di atas dapat diketahui,nilai signifikansi untuk seluruh variabel independen (pendidikan kewirausahaan, keterampilan, dan lingkungan) lebih besar daripada nilai alpha. Dengan demikian dapat disimpulkan bahwa
dUmaka $(1,620<1,764<2,380)$. Maka dapat disimpulkan tidak terdapat autokorelasi pada model regresi ini.

Regresi Linier Berganda

Tabel 7 Regresi Linear Berganda

Coefficients ${ }^{a}$

\begin{tabular}{|c|c|c|c|c|c|c|c|c|}
\hline \multirow[b]{2}{*}{ Mode } & & \multicolumn{2}{|c|}{$\begin{array}{l}\text { Unstandardized } \\
\text { Coeff icients }\end{array}$} & \multirow{2}{*}{$\begin{array}{c}\text { Standardized } \\
\text { Coeff icients }\end{array}$} & \multirow[b]{2}{*}{$t$} & \multirow[b]{2}{*}{ Sig. } & \multicolumn{2}{|c|}{ Collinearity Statistics } \\
\hline & & $\mathrm{B}$ & Std. Error & & & & Tolerance & VIF \\
\hline \multirow[t]{4}{*}{1} & (Constant) & ,681 & ,242 & & 2,818 & ,009 & & \\
\hline & Pendidikan & ,158 & ,116 & 174 & 1,367 & ,183 & 257 & 3,898 \\
\hline & Keterampilan & 1,094 & , 192 & 1,137 & 5,705 &, 000 & , 105 & 9,568 \\
\hline & Lingkungan &,- 419 &, 128 &,- 449 & $-3,262$ &, 003 & ,219 & 4,560 \\
\hline
\end{tabular}

a. Dependent Variable: Minat

Berdasarkan tabel 4.17 diatas maka diperoleh persamaan regresi linier berganda sebagai berikut :

1. Nilai konstanta sebesar 0,681 berarti jika variabel Pendidikan Kewirausahaan (X1), Keterampilan (X2), dan Lingkungan (X3) bernilai tetap (0), maka data dalam penelitian ini tidak terindikasi gejala heteroskedastisitas. Ghozali (2013; 139) mengemukakan ketika hasil uji glesjer menunjukkan nilai yang tidak signifikan (Sig > 0,05), maka data tersebut bebas dari gejala heteroskedastisitas. 
0,158 berarti jika Pendidikan Kewirausahaan (X1) naik satu satuan maka Minat Berwirausaha akan meningkat sebesar 0,158 .

3. Nilai koefisien regresi variabel Keterampilan (X2) sebesar 1,904 berarti jika Keterampilan (X2) naik satu satuan maka Minat Berwirausaha akan meningkat sebesar 1,904.

4. Nilai koefisien regresi variabel Lingkungan (X3) sebesar -0,491 berarti jika Lingkungan (X3) naik satu satuan maka Minat Berwirausaha akan menurun sebesar 0,491.

\section{Koefisien Determinasi}

Hasil analisis menunjukkan bahwa koefisien determinasi (Adjusted R Square) sebagai berikut :

Tabel 8 Hasil Koefisien Determinasi $\left(\mathbf{R}^{2}\right)$

\begin{tabular}{|c|c|c|c|c|}
\hline & $\mathbf{R}$ & R Square & Adjusted R Square & Std. Error of the Estimate \\
\hline 1 & $.942(\mathrm{a})$ & .888 & .875 & .26904 \\
\hline
\end{tabular}

Dilihat dari tabel 4.18, hasil Adjusted $\mathrm{R}$ Square $=0,875$ dapat dikatakan perubahan variabel dependen Minat Berwirausaha (Y) sebesar 87,5\% disebabkan oleh variabelPendidikan Kewirausahaan (X1), Keterampilan (X2), dan Lingkungan (X3), sedangkan 12,5\% disebebkan oleh faktor lain yang tidak ada dalam model ini.

\section{Pengujian Hipotesis Parsial}

Hasil uji t dengan menggunakan SPSS sebagai berikut :

Tabel 9 Hasil Uji Parsial (Uji t)

Coefficients

\begin{tabular}{|c|c|c|c|c|c|c|c|c|}
\hline \multirow[b]{2}{*}{ Mod } & & \multicolumn{2}{|c|}{$\begin{array}{l}\text { Unstandardized } \\
\text { Coefficients }\end{array}$} & \multirow{2}{*}{$\begin{array}{l}\text { Standardized } \\
\text { Coeff icients } \\
\text { Beta }\end{array}$} & \multirow[b]{2}{*}{$\mathrm{t}$} & \multirow[b]{2}{*}{ Sig. } & \multicolumn{2}{|c|}{ Collinearity Statistics } \\
\hline & & B & Std. Error & & & & Tolerance & VIF \\
\hline \multirow[t]{4}{*}{1} & (Constant) & ,681 & ,242 & & 2,818 &, 009 & & \\
\hline & Pendidikan & 158 & ,116 & 174 & 1,367 & , 183 & 257 & 3,898 \\
\hline & Keterampilan & 1,094 & ,192 & 1,137 & 5,705 & ,000 & , 105 & 9,568 \\
\hline & Lingkungan &,- 419 & 128 &,- 449 & $-3,262$ & ,003 & ,219 & 4,560 \\
\hline
\end{tabular}

a. Dependent Variable: Minat

1. Variabel Pendidikan Kewirausahaan ( $\mathrm{X} 1$ )

Berdasarkan perhitungan diperoleh nilai signifikansi sebesar 0,183 dan $\mathrm{t}$ hitung sebesar 1,367 lebih kecil dari t tabel 2,051. Berdasarkan uraian di atas maka dapat disimpulkan bahwa $\mathrm{H}_{0}$ ditolak dan $\mathrm{H}_{1}$ diterima. Sehingga dapat diambil kesimpulan bahwa variabel Pendidikan Kewirausahaan (X1) tidak berpengaruh terhadap Minat Berwirausaha(Y).

2. Variabel Keterampilan (X2)

Berdasarkan perhitungan diperoleh nilai signifikansi sebesar 0,000 dan $\mathrm{t}$ hitung sebesar 5,705lebih besar dari $\mathrm{t}$ tabel 2,051. Berdasarkan perhitungan diperoleh $\mathrm{t}$ hitung $(5,705)>\mathrm{t}$ tabel

Pengujian Hipotesis Simultan
$(2,051)$ maka dapat disimpulkan bahwa $\mathrm{H}_{0}$ ditolak dan $\mathrm{H}_{1}$ diterima. Sehingga dapat diambil kesimpulan bahwa variabel Keterampilan (X2) berpengaruh terhadap Minat Berwirausaha(Y).

3. Variabel Lingkungan Kerja ( X3 )

Berdasarkan perhitungan diperoleh nilai signifikansi sebesar 0,003 dan $\mathrm{t}$ hitung sebesar -3,362lebih besar dari $t$ tabel $-2,051$. Berdasarkan perhitungan diperoleh $t$ hitung $(-3,362)>t$ tabel (2,051) maka dapat disimpulkan bahwa $\mathrm{H}_{0}$ ditolak dan $\mathrm{H}_{1}$ diterima. Sehingga dapat diambil kesimpulan bahwa variabel Lingkungan (X3) berpengaruh terhadap Minat Berwirausaha (Y). 
Berdasarkan hasil regresi dalam program SPSS.15 maka dapat diproleh hasil uji simultan (uji F) sebagai berikut :

\section{Tabel 10 Hasil Uji Simultan (Uji F)}

ANOVA

\begin{tabular}{|c|c|c|c|c|c|c|}
\hline \multicolumn{2}{|c|}{ Model } & $\begin{array}{l}\text { Sum of } \\
\text { Squares }\end{array}$ & df & Mean Square & $\mathrm{F}$ & Sig. \\
\hline \multirow[t]{3}{*}{1} & Regression & 15,485 & 3 & 5,162 & 71,315 &, $000^{a}$ \\
\hline & Residual & 1,954 & 27 & , 072 & & \\
\hline & Total & 17,440 & 30 & & & \\
\hline
\end{tabular}

a. Predictors: (Constant), Lingkungan, Pendidikan, Keterampilan

b. Dependent Variable: Minat

Berdasarkan tabel 4.20 menunjukan nilai $\mathrm{F}$ hitung sebesar 71,315. Sedangkan F tabel pada tingkat signifikasi $5 \%$ dan $\mathrm{df} 1(\mathrm{~N} 1)=\mathrm{k}-1=4-1=3, \mathrm{df} 2(\mathrm{~N} 2)=31-4=$ 27, pada $\mathrm{F}$ tabel didapat angka sebesar 2,96. Ini berarti $\mathrm{F}$ hitung $>\mathrm{F}$ tabel $(71,315>2,96)$.

\section{HASIL DAN DISKUSI}

Berdasarkan hasil uji hipotesis yang tekah dilakukan, maka diketahui bahwa variabel Pendidikan Kewirausahaan (X1) tidak berpengaruh signifikan terhadap Minat Berwirausaha. Hasil ini sama dengan penelitian yang dilakukan oleh Ridwan dan Rahmanto (2011) yang menyatakan bahwa pendidikan kewirausahaan tidak berpengaruh secara signifikan terhadap minat berwirausaha pada siswa SMK di kota Bekasi. Disini peneliti juga menemukan fakta bahwa mayoritas responden mengaku bahwa pendidikan kewirausahaan yang ada di Universitas Muhammadiyah Gresik hanya sebatas teori atau pembelajarannya masih bertipe klasikal saja sedangkan pelatihan atau praktik wirausaha masih jarang diterapkan, sehingga mahasiswa kurang memiliki pengetahuan kewirausahaan yang memadai sebagai salah satu modal untuk menjadi seorang wirausahawan.

Hasil penelitian ini juga membuktikan bahwa variabel keterampilan memiliki pengaruh yang signifikan terhadap minat berwirausaha. Hasil penelitian ini juga

\section{SIMPULAN}

Pendidikan Kewirausahaan tidak mempunyai pengaruh signifikan terhadap minat berwirausaha Mahasiswa Universitas Muhammadiyah Gresik. Semakin tinggi pendidikan kewirausahaan yang didapat
Maka H0 ditolak dan H1 diterimadapat diartikan bahwa variabel Pendidikan Kewirausahaan (X1), Keterampilan (X2), dan Lingkungan (X3) secara bersama-sama (simultan) berpengaruh terhadap Minat Berwirausaha (Y).

konsisten dengan penelitian yang dilakukan oleh Falaly dan Ilyas (2016). Hasil penelitian ini juga membuktikan teori yang diungkapkan oleh Gibb dalam Irawan dan Mulyadi (2016) menyatakan, the process of entrepreneurship includes behaviors, skills and attributes belonging to a person inentrepreneurial education. Berdasarkan uraian tersebut dapat disimpulkan bahwa semakin tinggi keterampilan seseorang maka semakin tinggi minat untuk berwirausaha.

Hasil pengujian hipotesis dalam penelitian ini juga membuktikan adanya pengaruh dari variabel lingkungan terhadap minat berwirausaha. Hasil penelitian ini konsisten dengan penelitian yang dilakukan oleh Farida dan Nurkhin (2016), dan sekaligus membuktikan teori yang diungkapkan oleh Alma (2010:8) lingkungan dalam bentuk "role models" juga berpengaruh terhadap minat berwirausaha biasanya melihat kepada orang tua, saudara keluarga yang lain, teman, pasangan atau pengusaha lainya.

tidak serta merta menumbuhkan minat berwirausaha mahasiswa.

Keterampilan mempunyai pengaruh signifikan secara parsial terhadap minat berwirausaha Mahasiswa Universitas 
Muhammadiyah Gresik. Semakin baik keterampilan yang dimiliki maka semakin tinggi minat berwirausaha.Lingkungan mempunyai pengaruh signifikan secara parsial terhadap minat berwirausaha Mahasiswa Universitas Muhammadiyah Gresik. Ketika lingkungan mendukung untuk berwirausaha, maka minat berwirausaha mahasiswa akan semakin tumbuh. Hasil uji hipotesis melalui uji simultan (F) menyatakan bahwa Pendidikan Kewirausahaan, Keterampilan, dan Lingkungan mempunyai pengaruh signifikan secara simultan terhadap minat berwirausaha Mahasiswa Universitas Muhammadiyah Gresik.

\section{REKOMENDASI}

agi Universitas

Bagi pihak Universitas berdasarkan hasil penelitian ini hendaknya memprioritaskan keterampilan mahasiswa guna mendukung minat berwirausaha mahasiswa yang cukup besar. Langkah yang dapat dilakukan Universitas terkait meningkatkan keterampilan berwirausaha mahasiswa adalah dengan menambah jam terbang untuk praktik wirausaha. Sehingga mahasiswa akan mendapatkan pengalaman yang lebih dalam menjalani sebuah usaha. Selain itu, pihak universitas juga menetapkan standar kompetensi yang lebih baik dengan membuat standar atau target bahwa mahasiswa harus punya usaha sendiri selama berkuliah di universitas tersebut.

agi Penelitian Selanjutnya

Hendaknya penelitian selanjutnya memperluas cakupan penelitian dengan menambah jumlah sampel yakni mahasiswa di Universitas lain selain UMG. Kemudian penelitian selanjutnya juga diharapkan memasukkan variabel lain seperti faktor ketersediaan modal.

DAFTAR PUSTAKA

Alma, Buchari, 2010, Kewirausahaan : untukmahasiswa danumun, Alfa Beta, Bandung.

Amalia, Helga Nurul, 2015, Pengaruh PrestasiDan Lingkungan Terhadap Minat Berwirausaha Siswa Jurusan Pemasaran SMK Diponegoro Salatiga(Studi Pada Kelas XI Tahun
Ajaran 2014/2015), Skripsi, Fakultas

Ekonomi Universitas Negeri

Semarang, Semarang.

Ardiyani, N.P.P. \& Kusuma, A.A.G., 2016, Pengaruh Sikap, Pendidikan Dan Lingkungan Keluarga Terhadap Minat Berwirausaha, E-Jurnal Manajemen Universitas Udayana, 5 (8).

Djamarah, Syaiful Bahri, 2008, Psikologi Belajar, Rineka Cipta, Jakarta.

Falaly, Elsa Ardhilya \& Ilyas, 2016, Pengaruh Pelatihan Keterampilan Sapu Glagah Terhadap Minat Berwirausaha Pemuda Desa Gunungsari Kecamatan Pulosari, Journal of Nonformal Education, Vol. 2, No. 2, 2016.

Farida, S. \& Nurkhin, A., 2016, Pengaruh Pendidikan Kewirausahaan, Lingkungan Keluarga, Dan Self Efficacy Terhadap Minat Berwirausaha Siswa SMK Program Keahlian Akuntansi, Economic Education Analysis Journal, 5 (1).

Fauzi, Yuliyanna, 2016, BPS : Jumlah Pengangguran di Indonesia Menciut 530 orang, www.cnnindonesia.com, Diakses pada tanggal 20 Mei 2017.

Ghozali, Imam. 2013. "Aplikasi Analisis Multivariate dengan Program SPSS".Semarang : Badan Penerbit Undip.

Ghozali, Imam, 2013, Aplikasi Analisis Multivariate Dengan Program IBM SPSS 21 Update PLS Regresi, BPFE, Yogyakarta.

Irawan, A. \& Mulyadi, H., 2016, Pengaruh Keterampilan Wirausaha Terhadap Keberhasilan (Studi Kasus pada Distro Anggota Creative Independent Clothing Community USAHA di Kota Bandung). Journal of Business Management Education, 1(1), pp.216-226.

Kamayanti, Ari, 2016, Metodologi Konstruktif Riset Akuntansi : Membumikan Religiositas, Rumah Peneleh, Jakarta.

Khairani, Makmum, 2014, Psikologi Belajar, Aswaja Pressindo, Yogyakarta. 
Lestari, Retno Budi\& TrisnandiWijaya, 2012, Pengaruh PendidikanKewirausahaan Terhadap Minat Berwirausaha Mahasiswa di STIE MDP, STMIK MDP, dan STIE MUSI. Jurnal. STIE MDP.

Mahanani, Hanum Risfi, 2014, Analisis Pengaruh Faktor Internal dan Lingkungan Eksternal Terhadap Minat Berwirausaha (Studi Pada Siswa SMA Negeri 1 Malang, Skripsi, Fakultas Ekonomika dan Bisnis Universitas Diponegoro, Semarang.

Mudyaharjo, Redja, 2012, Pengantar Pendidikan, PT. Rajagrafindo Persada, Jakarta.

Notoatmodjo, Soekidjo, 2003, Pendidikan dan Perilaku Kesehatan, Rineka Cipta, Jakarta.

Nur, Indriantoro dan Bambang Supomo.2014. Metodologi Penelitian Bisnis. Yogyakarta: BPFE.

Oktarilis, S.N., 2012, Pengaruh FaktorFaktor Yang Dapat Memotivasi Mahasiswa Berkeinginan Wirausaha, Jurnal Ekonomi Manajemen, Universitas Gunadarma.

Praswati, A.N., 2014, Analisis Faktor-Faktor Yang Mempengaruhi MinatWirausaha Di Kalangan Mahasiswa Studi Kasus: Fakultas Ekonomi DanBisnis Universitas Muhammadiyah Surakarta,Jurnal
UniversitasMuhammadiyah

Surakarta.

Pratiwi, Yenny \& I Made Wardana, 2016, Pengaruh Faktor Internal dan Eksternal Terhadap Minat Berwirausaha Mahasiswa Fakultas Ekonomi dan Bisnis Universitas Udayana, E-Jurnal Manajemen Unud, Vol. 5, No. 8, 2016 : 52155242.

Rochayani, Umi et al., 2013, Pengaruh Faktor Sosiodemografi, Sikap, dan Kontekstualterhadap Niat Berwirausaha Siswa,Jurnal Kependidikan, 43(2): h: 154-163.

Sarwoko, E., 2011, Kajian empiris entrepreneur intention mahasiswa, Jurnal ekonomi bisnis, 16(2), pp.128-130.

Slameto, 2010,Belajar dan Faktor-Faktor yang Mempengaruhi, Jakarta, RinekaCipta.

Sugihartono dkk, 2007, Psikologi Pendidikan, UNY Press, Yogyakarta.

Sujarweni, V.W.2015.Metodologi penelitian bisnis \& Ekonomi.Pustaka Baru Pers, Yogyakarta.

Yusuf L.N. Syamsu, 2009, Psikologi perkembangan anak dan remaja,PT Remaja Rosdakarya, Bandung.

Zimmerer, Thomas W., dkk, 2008, Kewirausahaan dan Manajemen UsahaKecil. Salemba Empat, Jakarta. 